\title{
Drying of Onion Paste to Develop Powders by Foam-Mat Drying Process using Egg Albumin as Foaming Agent
}

\section{Javed Iqbal ${ }^{1}$, Rizwan Shukat ${ }^{1}$, Muhammad Farooq $^{2 *}$, Iftikhar Ahmed Solangi ${ }^{2}$, Naila Ilyas ${ }^{3}$, Rahman Ullah $^{4}$, A. Shakoor ${ }^{5}$, Muhammad Bakhtiar $^{6}$ and Faraz Ahmed ${ }^{7}$}

${ }^{1}$ Department of Food Technology National Institute of Food Science and Technology, University of Agriculture Faisalabad, Pakistan; ${ }^{2}$ College of Food Science and Engineering, Northwest A and F University, Yangling, Shaanxi712100, P.R. China; ${ }^{3}$ Graduate School of Chinese Academy of Agricultural Sciences, Beijing 100081, China; ${ }^{4}$ Faculty of Veterinary Sciences, Gomal University, Dera Ismail Khan, Pakistan; ${ }^{5}$ Beijing Key Laboratory of Quality Evaluation Technology for Hygiene and Safety of Plastic, Beijing Technology and Business. University, Beijing, 100048, China; ${ }^{6}$ Department of Agronomy, University of Agriculture Peshawar, Khyber Pakbtunkhwa, Pakistan; ${ }^{7}$ College of Food Science and Technology, Shanghai Ocean University, Shanghai, 201306, China.

Abstract | Onion (Allium cepa) is a biennial, herbaceous, winter seasoned and cross-pollinated bulb crop belonging to Family Alliaceae. High moisture content of onion render it to be affected by microbial and enzymatic spoilage. Drying is a very effective way to preserve onion for a long time. Onion powder was prepared by foam mat drying technique in which onion paste was treated with different concentration of soy protein $(0 \%, 4 \%, 8 \%$ and $12 \%)$ as foaming agent and Carboxyl methylcellulose $(0.5 \%)$ as foam stabilizer and these were dried in hot air tray drier at different temperatures $\left(55^{\circ} \mathrm{C}, 65^{\circ} \mathrm{C}\right.$ and $\left.75^{\circ} \mathrm{C}\right)$ with $3 \mathrm{~mm}$ sheet thickness of onion foams. Effect of different concentration of foaming agent and drying temperature was studied on moisture loss drying rate of onion paste. Increase in concentration of foaming agent significantly increased the drying rate from $0.422 \pm 0.169$ (Control) to $0.744 \pm 0.169$ (soy protein). Foamed onion paste were dried faster than un-foamed which decreased the drying time of 5 hours for foamed onion paste at $65^{\circ} \mathrm{C}$ and $75^{\circ} \mathrm{C}$. Foamed onion pastes were dried in 300,240 and $300 \mathrm{~min}$ at $55^{\circ} \mathrm{C}, 65^{\circ} \mathrm{C}$ and $75^{\circ} \mathrm{C}$ temperature respectively, with $12 \%$ concentration of soy protein as foaming agent while un-foamed pastes were dried in 600, 420 and 480 mints at $55^{\circ} \mathrm{C}, 65^{\circ} \mathrm{C}$ and $75^{\circ} \mathrm{C}$ temperature respectively. Soy protein $12 \%$ and $65^{\circ} \mathrm{C}$ drying temperature was found best for drying of onion paste to develop powder.

Received | February 02, 2021; Accepted | March 15, 2021; Published | May 31, 2021

*Correspondence | Muhammad Farooq, College of Food Science and Engineering, Northwest A and F University, Yangling, Shaanxi712100, P.R. China; Email: farooq.fst28@gmail.com

Citation | Iqbal, M.J., R. Shukat, M. Farooq, I.A. Solangi, N. Ilyas, R. Ullah, A. Shakoor, M. Bakhtiar and F. Ahmed. 2021. Drying of onion paste to develop powders by foam-mat drying process using egg albumin as foaming agent. Pakistan Journal of Agricultural Research, 34(2): $431-437$.

DOI | http://dx.doi.org/10.17582/journal.pjar/2021/34.2.431.437

Keywords | Onion paste, Egg albumin, Foam-mat drying process

\section{Introduction}

$\mathrm{P}$ reservation of food has been a keen interest of human beings to increase the shelf life and to make the availability of food material for a long time. In the season fruits and vegetables are available in surplus amount and if these food materials are not preserved by any mean then it may result into wastage off these food materials. It is reported that in developing countries almost $40 \%$ of our agricultural products are wasted due to lack of proper processing, preservation and storage facilities for these produce (Lombard et al., 2008). These food spoilages may come from many sources during harvesting, handling, processing and 
storage of foods but most important are microbial and chemical spoilages (Gram et al., 2002). Vegetables are considered most susceptible to spoilage due to the microbial attack and various kind of chemical changes (Tournas, 2005). And if these spoiled foods which harbor a high load of microbes are consumed result in to several kind of human health complication because of foodborne pathogens in spoiled food materials (Abadias et al., 2008). Different kind of the microbes highly dependent upon the availability of water and the vegetables containing higher water activity have much more chances to be spoiled because of these microorganisms.

Dehydration or drying is the most efficient way to reduce the water activity of these kind of vegetables to prevent their spoilage (Mayor et al., 2004; Koc et al., 2008). There are number of food preservation techniques such as canning, curing, fermenting or acidifying and dehydration. Among all of these dehydration is most important and widely used because of being cost effective in term of packaging, storage and transportation of food material (Chavan and Amarowicz, 2012). Dehydration is one of the oldest method of food preservation in which water is removed or made unavailable in food materials. As water is the main component of the food which is required for microbial and enzymatic activity, more over chemical reactions also take place in availability of water. So, that is a water activity of different vegetables which define their stability (Farkas, 2007).

Market value of dehydrated vegetables is increasing in many countries due their stability and longer shelf life as compare to fresh vegetables (Zhang et al., 2006). Vegetables are dried by application of heat which evaporate their water contents. There are different methods for drying of vegetables like as sun drying, freeze drying, microwave drying, vacuum drying and infrared drying. Vegetables have many compounds such as phenolic and vitamins and these compounds are very sensitive to high temperature that's why selection of the drying technique depends upon final quality of end product, cost and many others factors, which should be kept in mind during selection of appropriate drying technique (Sagar and Kumar, 2010). A new technique name as foam-mat drying which is highly suitable for those foods which are sticky, very viscous and sensitive to high temperature, variety of food material can be dried by this technique with minimum quality changes (Kadam et al., 2010).
Many researchers conducted experiments to study the foam-mat drying process for (Kadam et al., 2012) pineapple, (Dehghannya et al., 2018) lime juice, (Sankat et al., 2004) banana, (Zheng et al., 2009) black currant pulp and (Alakali et al., 2009) mango pulp to develop powders. All they have found that drying with foaming treatment increased the drying rate and minimized the quality changes by decreasing the water activity of powders. Our present study is also about foam-mat drying of onion paste and to investigate the effect of different concentration of soy protein as a foaming agent on moisture loss and drying rate of onion paste.

\section{Materials and Methods}

\section{Procurement and preparation of raw material}

Onions were purchased from a local vegetable market, sorted for good quality without bruises, cuts and microbial attacks. Which were peeled off, washed and grinded with grinder and converted into paste in fruits and vegetable lab at Institute of Food Science and Technology, Soy protein was purchased from a scientific store (Abdullha Traders) Faisalabad and used as a foaming agent in different concentration.

\section{Development of onion foams by soy protein}

Onion paste weighing $200 \mathrm{~g}$ was taken for each experiment and treated with different concentration of soy protein $(0 \%, 4 \%, 8 \%$ and $12 \%)$ as foaming agent. Carboxyl Methyl cellulose $(0.5 \%)$ was used as a foam stabilizer. Onion paste, foaming agent and foam stabilizer in determined concentration were mixed in a $1000 \mathrm{ml}$ beaker and beating was done for 3 minutes to increase surface area of onion paste by developing stable foams with incorporation of maximum amount of air in onion paste by using a small scale hand beater used in kitchen for beating of eggs.

\section{Foam spreading in trays and drying}

Foams of onion paste subjected to different concentration of soy protein $(0 \%, 4 \%, 8 \%$ and $12 \%)$ as foaming agent were spread to $3 \mathrm{~mm}$ sheet thickness on aluminum foils and placed in stainless steel trays. Commercially available hot air tray dryer (Model\# R-5A, Serial\# 10-213, Commercial dehydrator systems, Inc.) was used for drying experiment in fruits and vegetable lab at Institute of Food Science and Technology, Drying was carried out in 3 batches, first batch was dried at $55^{\circ} \mathrm{C}$ comprising on four samples, one (Controlled) not treated with any foaming agent 
while three others which were treated with $4 \%, 8 \%$ and $12 \%$ concentration of soy protein, respectively. All the four samples were prepared again with same above mentioned concentrations of foaming agent and dried at $65^{\circ} \mathrm{C}$ and $75^{\circ} \mathrm{C}$. During drying experiment after each 60 minutes' weight of all samples were recorded and when constant weight was appeared, all the samples from the dryer were removed and placed in desiccator.

\section{Milling and storage of powder}

All the samples were removed from the desiccator and grounded in a grinder to develop free flowing powders. All the samples were stored at room temperature in polythene bags.

\section{Moisture loss and drying rate}

During the drying experiments of onion foams developed by different concentration of soy protein as foaming agent at different drying temperatures. Weight of each sample was recoded after an hour by a weighing balance, which was used to determine the decrease in moisture content of onion foams during drying process. Initial moisture content in onion foams were calculated by AOAC (2017) standard method of moisture calculation. Final moisture content of onion powders was also measured. By using the data of decrease in moisture of different samples drying rate was calculated by using $\Delta \mathrm{X} / \Delta \mathrm{t}$.

\section{Drying curves}

Drying curves for moisture loss and drying rate was plotted by using the data of moisture loss $\mathrm{X}$ from onion foams and drying rate $\Delta \mathrm{X} / \Delta \mathrm{t}$ verses time. Drying curves give information to know about exact drying time where these onion foams are dried. By these drying curves we can have idea about the best concentration of soy protein and temperature where sample dried in minimum time.

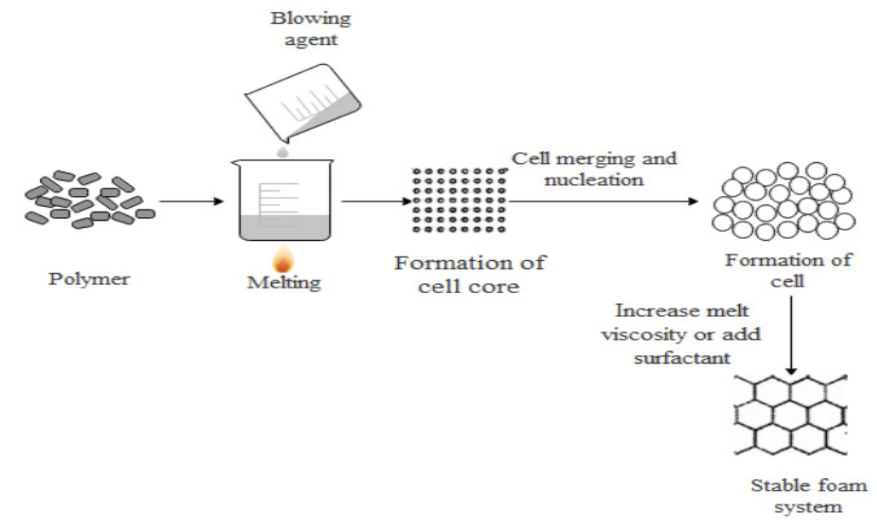

Schematic diagram of the foaming process system
Results and Discussion

Onion powder was produced by using soy protein in different concentration levels. Data for moisture loss for onion powders developed by different concentration levels of soy protein as foaming agent for which values are given in Tables 1,2 and 3 which were used to draw drying curves for moisture loss which can be seen in Figures 1,2 and 3 for drying at $55^{\circ} \mathrm{C}, 65^{\circ} \mathrm{C}$, and $75^{\circ} \mathrm{C}$. From the available data it was observed that moisture content decreased with time. Analysis of variance (ANOVA) showed highly significant effect of foaming agent and temperature $(\mathrm{P}<0.01)$. Foaming treatment resulted in faster drying as compare to non-foamed onion paste drying. Drying was fast for all above experiments in which foaming agents was used. Initially $200 \mathrm{~g}$ onion paste sample was taken which contained $184 \mathrm{~g}$ of moisture content and dried to achieve constant weight in try drier at $55^{\circ} \mathrm{C}, 65^{\circ} \mathrm{C}$ and $75^{\circ} \mathrm{C}$. At $55^{\circ} \mathrm{C}$ onion paste without foaming agent (Control) take 10 hours to dry while onion pastes subjected to different concentration of soy protein dried faster and saved 5 hours which can be seen in Table 1. As foaming treatment increases the surface area for drying which is resulted in better and faster removal of moisture content from onion paste. While removal of moisture from un-foamed onion paste was slow because of dense structure which resulted in slow moisture reduction. Increase in concentration of foaming agent resulted in faster drying. Fastest drying of onion paste at $55^{\circ} \mathrm{C}$ was observed for $12 \%$ concentration of soy protein as foaming agent. As indicated in Figures 1, 2 and 3 increases in temperature resulted in significantly drop in moisture content of onion powders. Dehghannya (2019); Kadam et al. (2011) reported similar results. In this research descending trend in moisture content of onion powders were observed with increase in temperature for which values are given in Tables 1,2 and 3.

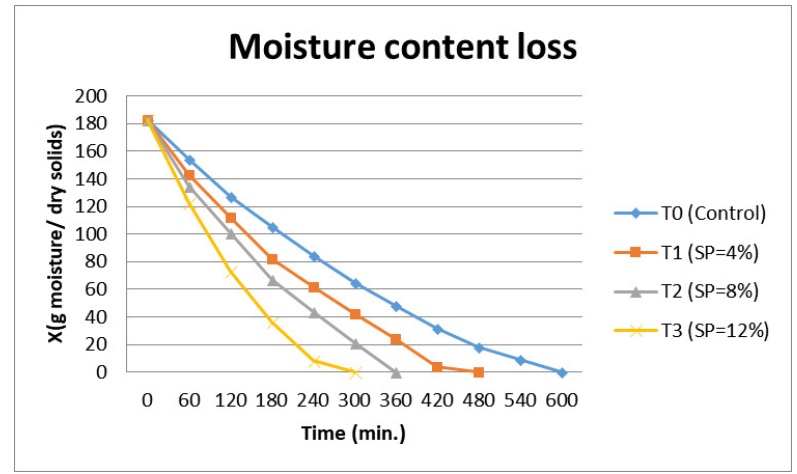

Figure 1: Effect of soy protein concentration level on moisture during foam mat drying of onion paste at $55^{\circ} \mathrm{C}$. 


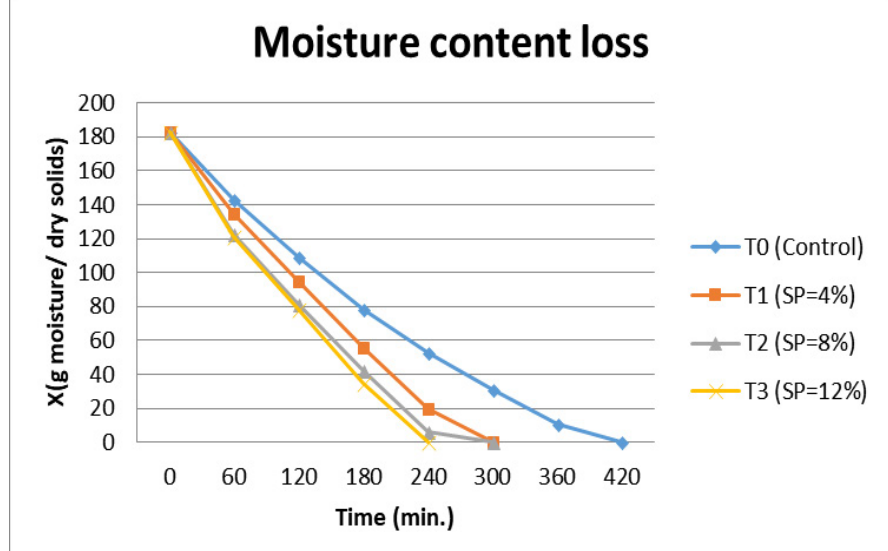

Figure 2: Effect of soy protein concentration level on moisture during foam mat drying of onion paste at $65^{\circ} \mathrm{C}$.

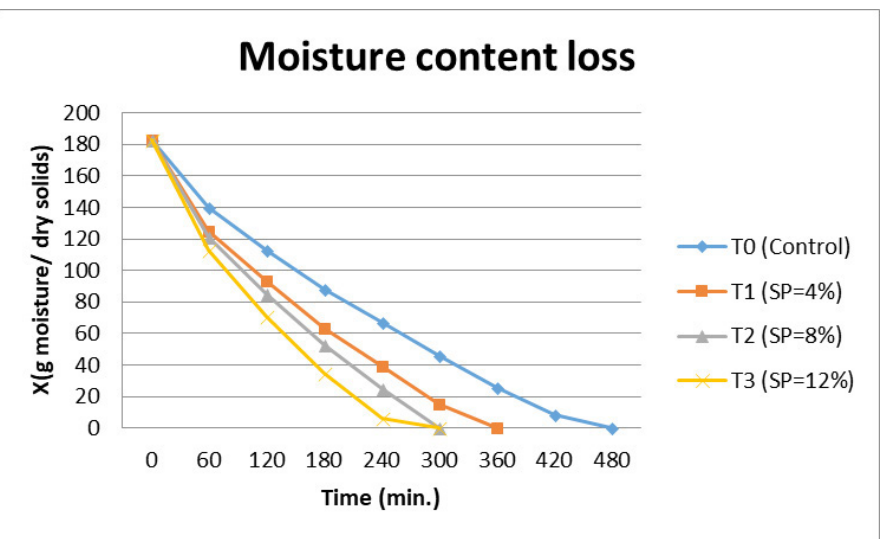

Figure 3: Effect of soy protein concentration level on moisture during foam mat drying of onion paste at $75^{\circ} \mathrm{C}$.

Table 1: Moisture loss from onion paste drying at $55^{\circ} \mathrm{C}$ temperature using different concentration of soy protein as foaming agent.

\section{Drying of onion paste at $55^{\circ} \mathrm{C}$ temperature}

S. Time, $\mathrm{t}$ Moisture content, $\mathrm{X}$ (g moisture/g dry solid) No. (min)

$\begin{array}{llllll}\text { Treatments } & \mathrm{T}_{0} \text { (Control) } & \begin{array}{l}\mathrm{T}_{1} \\ (\mathrm{SP}=4 \%)\end{array} & \begin{array}{l}\mathrm{T}_{2} \\ (\mathrm{SP}=8 \%)\end{array} & \begin{array}{l}\mathrm{T}_{3} \\ (\mathrm{SP}=\mathbf{1 2 \%})\end{array} \\ 2 & 0 & 183 & 183 & 183 & 183 \\ 3 & 120 & 127 & 143 & 135 & 123 \\ 4 & 180 & 105.3 & 82 & 67 & 36 \\ 5 & 240 & 84 & 62 & 44 & 8 \\ 6 & 300 & 64.7 & 42 & 21 & 0 \\ 7 & 360 & 48.4 & 24 & 0 & \\ 8 & 420 & 32 & 4 & & \\ 9 & 480 & 18.5 & 0 & & \\ 10 & 540 & 9 & & & \\ 11 & 600 & 0 & & & \end{array}$

Table 2: Moisture loss from onion paste drying at $65^{\circ} \mathrm{C}$ temperature using different concentration of soy protein as foaming agent.

\section{Drying of onion paste at $65^{\circ} \mathrm{C}$ temperature}

S. Time, $\mathrm{t}$ Moisture content, $\mathrm{X}$ (g moisture/g dry solid) No. (min)

Treatments

$\begin{array}{lll} & & \text { trol) } \\ 1 & 0 & 183 \\ 2 & 60 & 143 . \\ 3 & 120 & 109 \\ 4 & 180 & 78 \\ 5 & 240 & 53 \\ 6 & 300 & 31 \\ 7 & 360 & 11 \\ 8 & 420 & 0\end{array}$

Table 3: Moisture loss from onion paste drying at $75^{\circ} \mathrm{C}$ temperature using different concentration of soy protein as foaming agent.

\section{Drying of onion paste at $75^{\circ} \mathrm{C}$ temperature}

S. Time, $\mathrm{t}$ Moisture loss, $\mathrm{X}$ ( $\mathrm{g}$ moisture/g dry solid) No. (min)

$\begin{array}{llllll}\text { Treatments } & \begin{array}{l}\mathrm{T}_{0} \text { (Con- } \\ \text { trol) }\end{array} & \begin{array}{l}\mathrm{T}_{1} \\ (\mathrm{SP}=4 \%)\end{array} & \begin{array}{l}\mathrm{T}_{2} \\ (\mathrm{SP}=8 \%)\end{array} & \begin{array}{l}\mathrm{T}_{3} \\ (\mathrm{SP}=12 \%)\end{array} \\ 1 & 0 & 183 & 183 & 183 & 183 \\ 2 & 60 & 140.3 & 125 & 121 & 113 \\ 3 & 120 & 113 & 93 & 85 & 71 \\ 4 & 180 & 88 & 63 & 53 & 35 \\ 5 & 240 & 67 & 39 & 25 & 6 \\ 6 & 300 & 46 & 15 & 0 & 0 \\ 7 & 360 & 26 & 0 & & \\ 8 & 420 & 8 & & & \\ 9 & 480 & 0 & & & \end{array}$

Drying rate was calculated and used to draw drying rate curves for which data is given in Tables 4, 5 and 6. Drying rate for the onion powder at $55^{\circ} \mathrm{C}, 65^{\circ} \mathrm{C}$ and $75^{\circ} \mathrm{C}$ were evaluated by drying curves shown in Figures 4, 5 and 6 for drying at $55^{\circ} \mathrm{C}, 65^{\circ} \mathrm{C}$ and $75^{\circ} \mathrm{C}$. Drying curves were drawing with the data on the rate of drying versus time. Falling rate period was observed with passage of time because in start of the drying onion paste contains very high water content while with the passage of time during drying water content decrease and it became hard to remove moisture from inside of the sample. Hence, drying rate decreases with time. Mean values for drying rate of onion paste 
Table 4: Drying rate of onion paste at $55^{\circ} \mathrm{C}$ using different concentration of soy protein as foaming agent.

S. No. Time

\begin{tabular}{lll}
\multicolumn{2}{l}{ Treatments } & $\mathrm{T}_{0}$ (Control) \\
1 & 0 & 0 \\
2 & 60 & $0.453 \pm 0.025$ \\
3 & 120 & $0.423 \pm 0.025$ \\
4 & 180 & $0.350 \pm 0.017$ \\
5 & 240 & $0.346 \pm 0.025$ \\
6 & 300 & $0.330 \pm 0.017$ \\
7 & 360 & $0.286 \pm 0.016$ \\
8 & 420 & $0.243 \pm 0.025$ \\
9 & 480 & $0.193 \pm 0.023$ \\
10 & 540 & $0.130 \pm 0.026$ \\
11 & 600 & $0.156 \pm 0.011$ \\
12 & 660 & 0
\end{tabular}

\section{Drying rate at $55^{\circ} \mathrm{C}, \mathrm{N}\left(\mathrm{g} / \mathrm{cm}^{2} \mathrm{~min}\right)$}

$\begin{array}{lll}\mathrm{T}_{1}(\mathrm{SP}=4 \%) & \mathrm{T}_{2}(\mathrm{SP}=8 \%) & \mathrm{T}_{3}(\mathrm{SP}=\mathbf{1 2 \%}) \\ 0 & 0 & 0 \\ 0.656 \pm 0.012 & 0.790 \pm 0.010 & 0.986 \pm 0.015 \\ 0.520 \pm 0.020 & 0.560 \pm 0.010 & 0.783 \pm 0.042 \\ 0.503 \pm 0.015 & 0.563 \pm 0.012 & 0.660 \pm 0.035 \\ 0.306 \pm 0.021 & 0.380 \pm 0.020 & 0.440 \pm 0.017 \\ 0.303 \pm 0.023 & 0.393 \pm 0.015 & 0.120 \pm 0.017 \\ 0.283 \pm 0.015 & 0.350 \pm 0.020 & 0 \\ 0.330 \pm 0.010 & 0 & \end{array}$

$0.070 \pm 0.010$

0

Table 5: Drying rate of onion paste at $65^{\circ} \mathrm{C}$ using different concentration of soy protein as foaming agent.

\section{S. No. Time}

$\begin{array}{lll}\text { Treatments } & \mathrm{T}_{0} \text { (Control) } \\ 1 & 0 & 0 \\ 2 & 60 & 0.650 \pm 0.010 \\ 3 & 120 & 0.570 \pm 0.010 \\ 4 & 180 & 0.503 \pm 0.015 \\ 5 & 240 & 0.423 \pm 0.050 \\ 6 & 300 & 0.346 \pm 0.025 \\ 7 & 360 & 0.306 \pm 0.020 \\ 8 & 420 & 0.153 \pm 0.025 \\ 9 & 480 & 0\end{array}$

Drying rate at $65^{\circ} \mathrm{C}, \mathrm{N}\left(\mathrm{g} / \mathrm{cm}^{2} \mathrm{~min}\right)$

$\begin{array}{lll}\mathrm{T}_{1}(\mathrm{SP}=4 \%) & \mathrm{T}_{2}(\mathrm{SP}=8 \%) & \mathrm{T}_{3}(\mathrm{SP}=12 \%) \\ 0 & 0 & 0 \\ 0.806 \pm 0.020 & 1.013 \pm 0.015 & 1.006 \pm 0.020 \\ 0.630 \pm 0.026 & 0.650 \pm 0.026 & 0.710 \pm 0.017 \\ 0.663 \pm 0.005 & 0.626 \pm 0.025 & 0.693 \pm 0.023 \\ 0.593 \pm 0.005 & 0.610 \pm 0.034 & 0.566 \pm 0.011 \\ 0.323 \pm 0.030 & 0.596 \pm 0.015 & 0\end{array}$

0

0

Table 6: Drying rate of onion paste at $75^{\circ} \mathrm{C}$ using different concentration of soy protein as foaming agent.

\begin{tabular}{|c|c|c|c|c|c|}
\hline \multirow{2}{*}{\multicolumn{2}{|c|}{$\begin{array}{l}\text { S. No. Time } \\
\text { Treatments }\end{array}$}} & \multicolumn{4}{|c|}{ Drying rate at $75^{\circ} \mathrm{C}, \mathrm{N}\left(\mathrm{g} / \mathrm{cm}^{2} \mathrm{~min}\right)$} \\
\hline & & \multirow{2}{*}{$\begin{array}{l}\mathrm{T}_{0}(\text { Control }) \\
0\end{array}$} & \multirow{2}{*}{$\begin{array}{l}\mathrm{T}_{1}(\mathrm{SP}=4 \%) \\
0\end{array}$} & \multirow{2}{*}{$\begin{array}{l}\mathrm{T}_{2}(\mathrm{SP}=8 \%) \\
0\end{array}$} & \multirow{2}{*}{$\begin{array}{l}\mathrm{T}_{3}(\mathrm{SP}=12 \%) \\
0\end{array}$} \\
\hline 1 & 0 & & & & \\
\hline 2 & 60 & $0.700 \pm 0.010$ & $0.970 \pm 0.020$ & $1.016 \pm 0.011$ & $1.143 \pm 0.030$ \\
\hline 3 & 120 & $0.453 \pm 0.011$ & $0.516 \pm 0.023$ & $0.600 \pm 0.020$ & $0.703 \pm 0.015$ \\
\hline 4 & 180 & $0.436 \pm 0.015$ & $0.493 \pm 0.011$ & $0.523 \pm 0.011$ & $0.586 \pm 0.011$ \\
\hline 5 & 240 & $0.340 \pm 0.017$ & $0.416 \pm 0.015$ & $0.473 \pm 0.015$ & $0.486 \pm 0.005$ \\
\hline 6 & 300 & $0.333 \pm 0.015$ & $0.413 \pm 0.032$ & $0.416 \pm 0.005$ & $0.103 \pm 0.015$ \\
\hline 7 & 360 & $0.296 \pm 0.012$ & $0.220 \pm 0.030$ & 0 & 0 \\
\hline 8 & 420 & $0.136 \pm 0.011$ & 0 & & \\
\hline 9 & 480 & 0 & & & \\
\hline
\end{tabular}

Table 7: Mean drying rate of onion powder dried at different temperatures $\left(55^{\circ} \mathrm{C}, 65^{\circ} \mathrm{C}\right.$ and $\left.75^{\circ} \mathrm{C}\right)$ using different concentration of soy protein as foaming agent.

$\begin{array}{llllll}\text { S. No } & \text { Temperature } & \mathrm{T}_{0}(\text { Control }) & \mathrm{T}_{1}(\mathrm{SP}=4 \%) & \mathrm{T}_{2}(\mathrm{SP}=8 \%) & \mathrm{T}_{3}(\mathrm{SP}=12 \%) \\ 1 & 55^{\circ} \mathrm{C} & 0.291 \pm 0.109 & 0.371 \pm 0.273 & 0.506 \pm 0.273 & 0.598 \pm 0.273 \\ 2 & 65^{\circ} \mathrm{C} & 0.422 \pm 0.169 & 0.603 \pm 0.169 & 0.699 \pm 0.169 & 0.744 \pm 0.169 \\ 3 & 75^{\circ} \mathrm{C} & 0.385 \pm 0.174 & 0.512 \pm 0.174 & 0.606 \pm 0.174 & 0.604 \pm 0.174\end{array}$

June 2021 | Volume 34 | Issue 2 | Page 435 


\section{Drying rate at $55^{\circ} \mathrm{C}$}

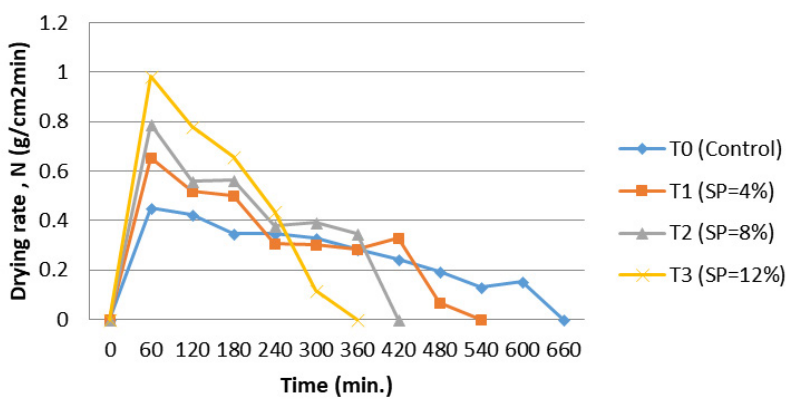

Figure 4: Effect of soy protein concentration level on drying rate of foam mat dried onion paste at $55^{\circ} \mathrm{C}$.

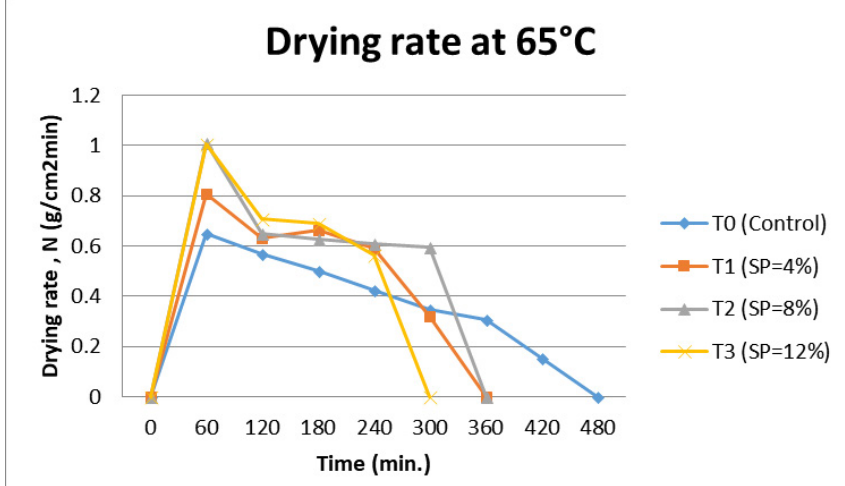

Figure 5: Effect of soy protein concentration level on drying rate of foam mat dried onion paste at $65^{\circ} \mathrm{C}$.

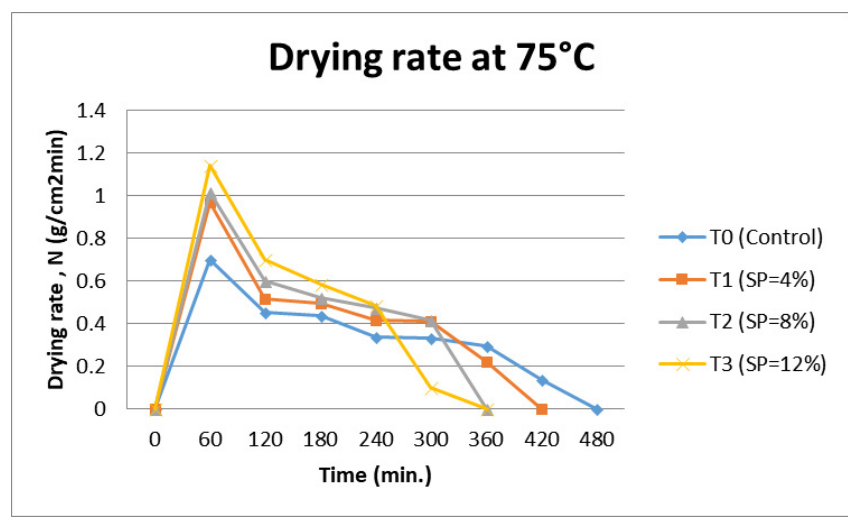

Figure 6: Effect of soy protein concentration level on drying rate of foam mat dried onion paste at $75^{\circ} \mathrm{C}$.

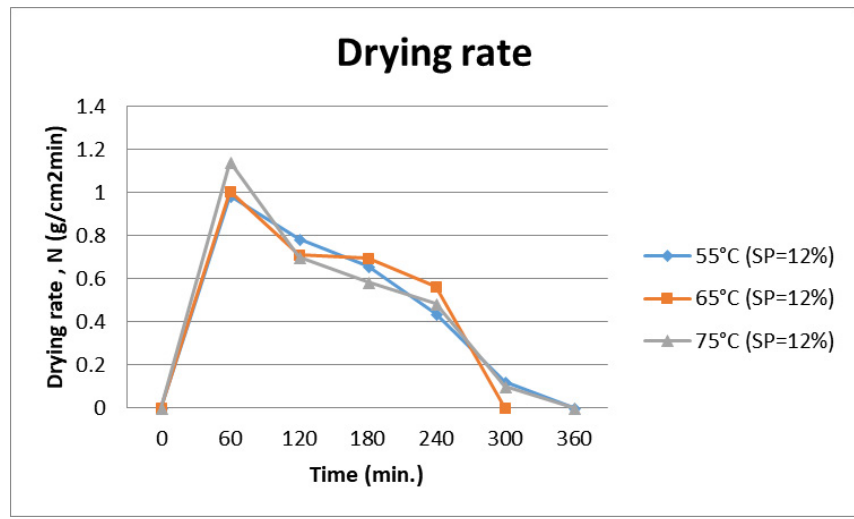

Figure 7: Effect of different temperatures $\left(55^{\circ} \mathrm{C}, 65^{\circ} \mathrm{C}\right.$ and $75^{\circ} \mathrm{C}$ ) on drying rate of onion powders developed by $12 \%$ soy protein as foaming agent. dried at $55^{\circ} \mathrm{C}, 65^{\circ} \mathrm{C}$ and $75^{\circ} \mathrm{C}$ by using different concentration of soy protein $(4 \%, 8 \%$ and $12 \%)$ as foaming agents are given in Table 7 . From the data it is shown that highest drying rate for soy protein $0.744 \pm 0.169$ at $65^{\circ} \mathrm{C}$ with $12 \%$ concentration.

\section{Conclusions and Recommendations}

Onion powder was prepared by foam-mat drying technique using soy protein in different concentration as foaming agent. Effect of foaming agent and different drying temperature was studied on moisture loss and drying rate of onion paste. From the results it was found that onion paste which was treated with different concentration of soy protein as foaming agent was dried in short time as compare to unfoamed onion paste. Moisture loss from foamed onion paste was higher because with foaming treatment surface area for drying was increased which resulted into faster and easy removal of moisture of foamed onion pastes. Moreover, drying rate of onion pastes which were treated with different concentration of soy protein was higher as compare to un-foamed onion pastes.

\section{Novelty Statement}

The present study will very helpful to understand Drying of Onion Paste With Using Egg Albumin

\section{Author's Contribution}

M. Javed Iqbal and Rizwan Shukat: Wrote the Original draft.

Muhammad Farooq: Reviewed and edited the whole article.

Iftikhar Ahmed Solangi: Wrote material and Methods.

Rahman Ullah and A. Shakoor: Reviewed the article.

Naila Ilyas: Helped in introduction.

Faraz Ahmed: Wrote the discussion.

Muhammad Bakhtiar: Wrote Material and Methods.

\section{Conflict of interest}

The authors have declared no conflict of interest.

\section{References}

Abadias, M., J. Usall, M. Anguera, C. Solsona and

June 2021 | Volume 34 | Issue 2 | Page 436 
I. Viñas. 2008. Microbiological quality of fresh, minimally-processed fruit and vegetables, and sprouts from retail establishments. Int. J. Food Microbiol., 123: 121-129. https://doi. org/10.1016/j.ijfoodmicro.2007.12.013

Alakali, J.S., C.C. Ariahu and E.I. Kucha. 2009. Kinetics of moisture uptake of osmo-foammat dried mango powders and application of sorption isotherms to shelf-life prediction. Am. J. Food Technol., 3: 119-125. https://doi. org/10.3923/ajft.2009.119.125

AOAC, 2017. Association of official analytical chemists. 2006. Official methods of analysis of AOAC. $18^{\text {th }}$ Ed. AOAC press, Arlington, VA, USA.

Chavan, U.D. and R. Amarowicz. 2012. Osmotic dehydration process for preservation of fruits and vegetables. J. Food Res., 1: 202. https://doi. org/10.5539/jfr.v1n2p202

Dehghannya, J., M. Pourahmad, B. Ghanbarzadeh and H. Ghaffari. 2018. Influence of foam thickness on production of lime juice powder during foam-mat drying: Experimental and numerical investigation. Powder Technol., 328: 470-484. https://doi.org/10.1016/j. powtec.2018.01.034

Dehghannya, J., M. Pourahmad, B. Ghanbarzadeh and H. Ghaffari. 2019. Heat and mass transfer enhancement during foam-mat drying process of lime juice: Impact of convective hot air temperature. Int. J. Thermal Sci., 135: 30-43. https://doi.org/10.1016/j. ijthermalsci.2018.07.023

Farkas, 2007. Physical methods of food preservation. In: Food microbiology: Fundamentals and frontiers, third edition. pp. 685-712. https:// doi.org/10.1128/9781555815912.ch32

Gram, L., L. Ravn, M. Rasch, J.B. Bruhn, A.B. Christensen and M. Givskov. 2002. Food spoilage interactions between food spoilage bacteria. Int. J. Food Microbiol., 78: 79-97. https://doi.org/10.1016/S01681605(02)00233-7

Kadam, D.M., R.T. Patil and P. Kaushik. 2010. Foam mat drying of fruit and vegetable products. In: Drying of Foods, Vegetables and Fruits-Volume 1, edited by Jangam S.V., Law C.L. and Mujumdar A.S., Published in Singapore.

Kadam, D.M., R.T. Patil and P. Kaushik. 2011.
Foam mat drying of fruit and vegetable products. In Drying of Foods, Vegetables and Fruits-Volume 1, edited by Jangam S.V., Law C.L. and Mujumdar A.S., Published in Singapore.

Kadam, D.M., R.A. Wilson, V. Kaur, S. Chadha, P. Kaushik, S. Kaur, R.T. Patil and D.R. Rai. 2012. Physicochemical and microbial quality evaluation of foam $\$ mat $\$ dried pineapple powder. Int. J. Food Sci. Technol., 47: 1654$1659 . \quad$ https://doi.org/10.1111/j.13652621.2012.03016.x

Koc, B., I. Eren and F.K. Ertekin. 2008. Modelling bulk density, porosity and shrinkage of quince during drying: The effect of drying method. J. Food Eng., 85: 340-349. https://doi. org/10.1016/j.jfoodeng.2007.07.030

Lombard, G.E.,J.C. Oliveira, P. Fito and A. Andrés. 2008. Osmotic dehydration of pineapple as a pre-treatment for further drying. J. Food Eng., 85: 277-284. https://doi.org/10.1016/j. jfoodeng.2007.07.009

Mayor, L. and A.M. Sereno. 2004. Modelling shrinkage during convective drying of food materials: A review. J. Food Eng., 61: 373-386. https://doi.org/10.1016/S02608774(03)00144-4

Sagar, V.R. and P.S. Kumar. 2010. Recent advances in drying and dehydration of fruits and vegetables: A review. J. Food Sci. Technol., 47: 15-26. https://doi.org/10.1007/s13197-0100010-8

Sankat, C.K. and F. Castaigne. 2004. Foaming and drying behaviour of ripe bananas. LWTFood Sci. Technol., 37: 517-525. https://doi. org/10.1016/S0023-6438(03)00132-4

Tournas, V.H., 2005. Spoilage of vegetable crops by bacteria and fungi and related health hazards. Crit. Rev. Microbiol., 31: 33-44. https://doi.org/10.1080/10408410590886024

Zhang, M., J. Tang, A.S. Mujumdar and S. Wang. 2006. Trends in microwave-related drying of fruits and vegetables. Trends Food Sci. Technol., 17: 524-534. https://doi. org/10.1016/j.tifs.2006.04.011

Zheng, X., C. Liu and H. Zhou. 2009. Drying characteristics of blackcurrant pulp by microwave-assisted foam mat drying. Trans. Chinese Soc. Agric. Eng., 25: 288-293. 